\title{
Impact of Relationship Marketing and Service Quality on Customer Satisfaction and Its Implications to Customer Loyalty in Pt. Precision Tools Service Indonesia (PTSI)
}

\author{
Robby Hakim Nugraha ${ }^{1}$, Arifin Sitio ${ }^{2}$ \\ ${ }^{1}$ Student of Magister Management, Mercu Buana University (UMB) \\ ${ }^{2}$ Lecturer of Magister Management, Mercu Buana University (UMB)
}

\begin{abstract}
This study aims to analyse the effect of relationship marketing and service quality on customer satisfaction and its implications on customer loyalty. Based on observations and interviews from June 8, 2018, that is using at PTSI outside of the marketing team, and customer loyalty is the primary goal of each team member. Customer loyalty also becomes an instruction of the administration that can see from the existence of the policy of daily visits to its clients. The population of this study is customers who made purchases in the last six months. The sample of this study is $\mathbf{1 0 0}$ clients of PT Precision Tooling Service Indonesia, which made purchases during the previous six months. The sampling method of this study using stratified random sampling. The analytical method used is path analysis. PROCESS Macro Hayes assists the data analysis used in this study in version 23 of SPSS. The results showed that (1) relationship marketing has a positive and significant effect on customer satisfaction, (2) service quality has a positive and significant impact on customer satisfaction, (3) relationship marketing has an effect positive and significant in customer loyalty to customers satisfaction as a full mediator, (4) service quality has a positive and significant effect on customer loyalty with customer satisfaction as a full mediator, and (5) customer satisfaction has a positive and significant impact on customer loyalty.
\end{abstract}

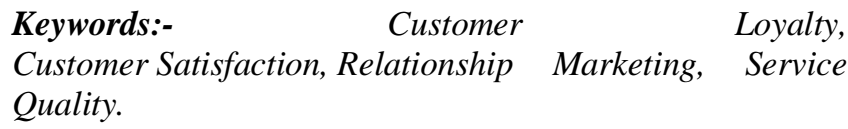

\section{INTRODUCTION}

The Indonesian automotive industry has become one of the significant pillars in the manufacturing and investment sector in Indonesia. Many car companies open car manufacturing factories and increase production capacity in Indonesia. According to the Association of Indonesia Automotive Industries (Gaikindo), one of the factors supporting car sales in Indonesia is the proportion of car owners per capita, which still low (less than $4 \%$ of the population having a car). It implies that there is a vast space for the sales growth of cars in Indonesia. This enormous space of sales growth positively encourages car manufacturing companies to continue innovating to compete for Indonesia's existing market share. Don't stop there; suppliers of car companies are also affected by investment activities carried out by car manufacturing companies. This is implemented in the form of innovation to support the supply of products and services that car manufacturing companies need.

Kotler and Armstrong (2014) stated that a company could survive by increasing its customers' commitment to being able to reorder the sold products rather than continuing to focus on finding new customers. This customer loyalty can reduce marketing costs but also maintain the existence of the company. In marketing theory, the buyer's commitment to buy back a product or service that the company is selling is called customer loyalty. Based on observations and interviews conducted on June 8, 2018, at PTSI's external marketing team, the goal of customer buyback is the primary goal of each team member. The marketing team upholds the principle that, according to superiors' directives, PTSI's sales success is not just selling goods or services but also the marketing team has the demand for building loyalty and satisfaction for its customers. To discover the factors influenced the loyalty and satisfaction, researchers conducted preliminary research interviewing 30 PTSI clients to find the primary triggers for their satisfaction and loyalty. 
Table 1. Factors influencing customer loyalty

\begin{tabular}{cccc}
\hline No & Indicators of loyalty problems & $\begin{array}{c}\text { Number of } \\
\text { people) }\end{array}$ & $\begin{array}{c}\text { Percentage } \\
(\%)\end{array}$ \\
\hline 1 & Service Quality & 11 & 36 \\
2 & Distribution speed & 3 & 11 \\
3 & Word of mouth & 1 & 4 \\
4 & Relational marketing & 15 & 49 \\
& Total & 30 & 100 \\
\hline
\end{tabular}

Source: Results of pre-study (2018)

Based on pre-study results, the factors that predominantly affect customer loyalty are known to be customer quality and relationship marketing. These results become a benchmark for researchers to examine the factors that influence PTSI's customer satisfaction and customer loyalty.

The low level of PTSI customer loyalty can be seen through customer buyback activities. Based on observations from June 8,2018 , researchers see customer buybacks remain low. The researchers distributed questionnaires to 8 PTSI marketing teams to get an overview of purchases made by PTSI customers. Of the eight questionnaires distributed, only seven were completed, and the data could be processed. The following table show an overview of the purchasing data made by PTSI customers during June 2018.

\begin{tabular}{cccccc}
\hline \multicolumn{6}{c}{ Table 2. PTSI customer purchase data in June 2018 } \\
\hline sales area & $\begin{array}{c}\text { Number of } \\
\text { clients }\end{array}$ & $\begin{array}{c}\text { Minimum } \\
\text { purchase of 1 } \\
\text { customer }\end{array}$ & $\begin{array}{c}\text { Maximum } \\
\text { purchase of 1 } \\
\text { customer }\end{array}$ & $\begin{array}{c}\text { Total } \\
\text { Purchases }\end{array}$ & $\begin{array}{c}\text { Repurchase } \\
\text { percentage }\end{array}$ \\
\hline Cibitung 1 & 12 & 1 & 81 & 145 & 55.86 \\
Cibitung 2 & 15 & 1 & 37 & 121 & 30.57 \\
Cibitung 3 & 39 & 1 & 67 & 187 & 35.83 \\
Jababeka 4 & 15 & 1 & 49 & 116 & 42.42 \\
Jababeka 5 & 15 & 1 & 9 & 51 & 17.65 \\
Karawang 1 & 25 & 1 & 48 & 162 & 29.63 \\
Karawang 2 & 19 & 1 & 18 & 76 & 23.68 \\
\hline
\end{tabular}

Source: Processed data (2018)

From Table 2, The potential buybacks from PTSI customers can still increase because in some sales areas have buyback percentage is still quite low, such as Jababeka 5 , which is only $17.65 \%$. This number of buyback percentage became the initial base that intrigued researchers to see PTSI's level of customer loyalty and satisfaction.

Furthermore, there are differences in the research results in previous studies. Research by Kumadji and Andriani (2014) shows that relationship marketing has a significant effect on customer satisfaction and loyalty. On the other hand, the research by Ansari and Wijaksana (2016) found that relationship marketing does not correlate to customer loyalty.

Research conducted by Tiasanty and Sitio (2019) also Amalia (2015) found that service quality has a significant effect on customer loyalty. That research is contrary to the research carried out by Kusumawati and Andarwati (2017) that establishes that the quality of the service does not have a significant impact on customer loyalty.

Based on the results of the study shown, as well as the gap research in previous studies, the researcher is interested in researching to find out if relationship marketing and service quality can be taken into account to increase PT. Precision Tools Service Indonesia, which will ultimately create customer loyalty.

\section{THEORETICAL REVIEW}

\section{Relationship marketing}

Relationship marketing is a philosophy or culture that combines processes and techniques business to understand customers of the company and convert them into customers always return to be loyal customers of the company. This relationship marketing is also a systematic approach to manage the relationship between company and its customers, which is mutually beneficial (Daryanto, 2011). According to Lovelock et al. (2012), relationship marketing describes the types of marketing activities that are designed to create long-term relationships with customers.

Relationship marketing describes a longterm relationship based on mutual interests between the company and the customer since both parties (sellers and buyers) focus on shared objectives (Cheng \& Lee, 2011). The basic idea of relationship marketing is long-term relation between company and customer. Potential customer can lead to a long-term profit stream for the 
company. This perspective reflects a paradigm shift that is significantly different from transactional marketing. The relationship marketing also reflects a change of marketing paradigm from competition and conflict to mutual cooperation. It's transform choice independence to the mutual interdependence (Tjiptono, 2014)

\section{Service Quality}

Regarding the definition of quality, it has a relative measure. The concept of quality is judged by its attributes, design, and suitability. Quality is a dynamic condition related to products and services. Other factor such as person, process, and environment that meet and exceed expectations also depended (Tjiptono, 2014). Furthermore, Alma (2013) defines service as invisible activities that cannot be touched. It occurs as a result of interactions between consumers and providers that intended to solve problems.

Rangkuti (2013) explains that the level of service quality could not be evaluated from the company. It must be seen from customer evaluation. Service quality has been conceptualised as the difference between the client's expectations regarding the service that will be received and the perception of the services received (Akbar and Parvez, 2009). Service quality can be explained as the customer's perception of the difference between the expected service and actual performance that can affect satisfaction levels. Therefore, when formulating service strategies and programs, companies must be oriented to the interests of customers, taking into account the Service Quality component.

\section{Customer satisfaction}

Customer satisfaction related to person's feeling of happy or disappointed that arise when they consuming a product or kind of services (Kotler and Keller, 2016). Arise of that feeling come from their comparing the value of product to their expectations. Meanwhile, Rangkuti (2013) stated that consumer satisfaction is a response or reaction to a mismatch between the level of the previous interest and performance of real sense after use or consumption. If the perceived value is below expectations, the customer will be unhappy. In the other side, when product value meets customer's expectations, satisfaction will arise.

Until now, the definition of customer satisfaction is still widely debated, and there are at least two types of domains. On the one hand, customer satisfaction is seen as the outcome or results obtained from the experience of consuming specific goods or services (resultsoriented approach). On the other hand, customer satisfaction is also often seen as a process (processororiented approach).

\section{Customer loyalty}

Loyalty literally means the quality of being loyal, that is someone's loyalty to an object. Loyalty is a condition in which customers have a positive attitude towards a brand, are committed to the brand and intend to continue their purchases in the future. At the core of customer loyalty is the customer's deep commitment to consistently repurchase or re-subscribe to selected products or services in the future. However, the influence of the situation has the potential to cause behavior change.

According to Assauri (2013), customer loyalty is the tendency of customers to choose the value of the organisation offered over the alternative offer of competing organisations. Meanwhile, according to Lovelock et al (2012), loyalty is the customer's decision to voluntarily continue to subscribe to companies for an extended period of time. In more general terms, Hasugian (2015) explains that customer loyalty as an option for a product or service and ensures that loyalty will have an impact on increasing a company's market share. Based on these definitions, it can be concluded that there are elements of behavior and attitude in customer loyalty. Customer loyalty is crucial for companies that maintain business continuity and continuity. Loyalty describes the expected behavior in relation to a product or service. Loyalty is the essential factor in improving a company's earnings performance.

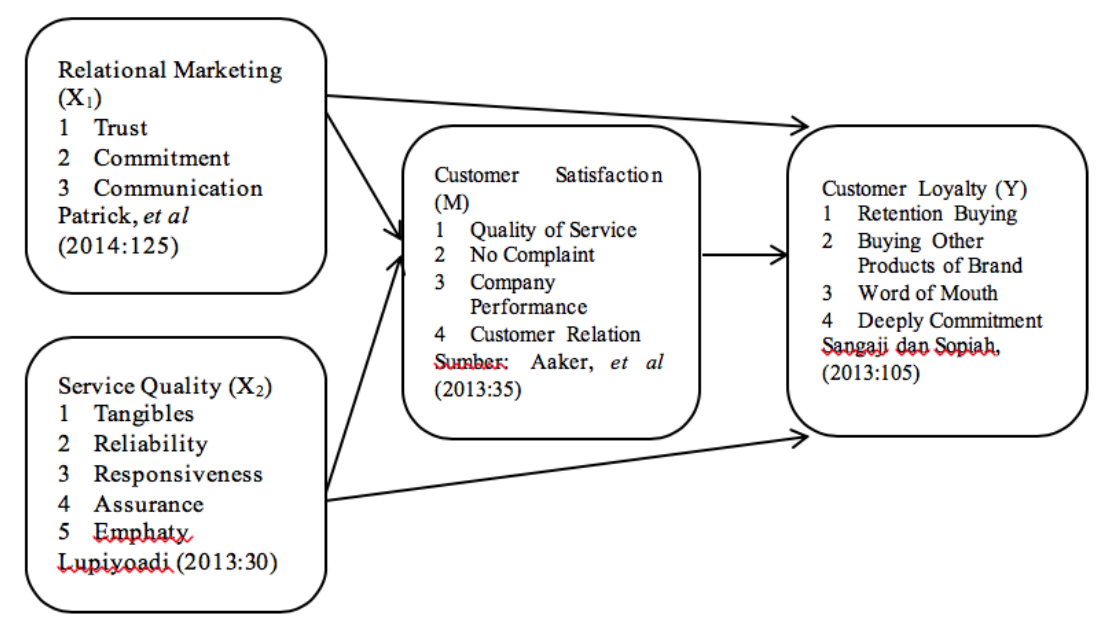

Figure 1. Research thinking framework 
From the introduction stated above, we predict that:

Hypothesis 1. Relationship marketing has a positive and significant effect on customer satisfaction.

$>$ Hypothesis 2. Service quality has a significant and positive impact on customer satisfaction.

Hypothesis 3. Relationship marketing has a positive and significant effect on customer loyalty with customer satisfaction as an intervening variable.

Hypothesis 4. Service quality has a positive and significant effect on customer loyalty with customer satisfaction as an intervening variable.

$>$ Hypothesis 5. Customer satisfaction has a significant and positive effect on customer loyalty.

\section{METHOD}

This research used descriptive-analytical aim to make a systematic, objective, and precise description. The data obtained using structured quantitative data. Questionnaire use Likert scale type range from totally agree to totally disagree.
Population in this study are PT. Precision Tool Service Indonesia customer who purchase within the last 6 months. The sampling is aimed at PT. Precision Tools Service Indonesia's clients have surveyed 100 users in the previous 6 months. Based on this, the sampling technique of this study, the authors used the stratified random sampling method.

Data was performed using the path analysis method assisted by the SPSS version 23 . The data analysis methods used in this study are in the form of Model Test 1 and Model Test 2.

\section{RESULTS AND DISCUSSION}

Data collection in this study was performed for 3 weeks from January 10th 2019. One hundred registered respondents completed this survey, and all respondents can be processed because all data is complete.

Table 3. Descriptive statistics of the research variables.

\begin{tabular}{cc}
\hline Variable & Average \\
\hline Relational marketing & 3.48 \\
Service Quality & 3,67 \\
Customer satisfaction & 3.57 \\
Customer loyalty & 3,61 \\
\hline
\end{tabular}

Source: Questionnaire, Data processed (2019)

After a descriptive analysis of the research variables, the model 1 test is performed to see the relationship between the relationship marketing variable and service quality with customer satisfaction as an intervening variable. The results of the analysis are illustrated in Table 4 below.

Table 4. T test results (partial test) Model 1

\begin{tabular}{|c|c|c|c|c|c|c|}
\hline & \multirow[t]{2}{*}{ Model } & \multicolumn{2}{|c|}{$\begin{array}{l}\text { standardized } \\
\text { coefficients }\end{array}$} & \multirow{2}{*}{$\begin{array}{c}\text { Standardized } \\
\text { coefficients }\end{array}$} & \multirow[t]{2}{*}{$\mathrm{t}$} & \multirow[t]{2}{*}{ Sig. } \\
\hline & & yes & Std. Error & & & \\
\hline \multirow{5}{*}{ one } & (Constant) & 1,886 & 1,353 & & 1,393 & .167 \\
\hline & Marketing & .627 & .105 & .571 & 5,993 & .000 \\
\hline & Relational & & & & & \\
\hline & Quality & .1010 & .081 & .364 & 3,823 & .000 \\
\hline & Service & & & & & \\
\hline
\end{tabular}

to. Dependent variable: Customer satisfaction

Source: SPSS 23 output, data processed.

From Table 4, it appears that Research Hypotheses 2 ( du a) can be answered as follows:

$>$ Relationship marketing influences customer satisfaction. This is due to the relational marketing get count $\mathrm{t}$-value is $5993>$ value of the ttable was $1.9847(\alpha=5 \%$, df $=97)$ with significant value $0.000<0.05, \mathrm{H} 0$ rejected and $\mathrm{H} 1$ accepted. Therefore can be conclude that relationship marketing has a significant effect on customer satisfaction.

The service quality affects customer satisfaction because the t-value $3823>$ value of the t-table was $1.9847(\alpha=5 \%, \mathrm{df}=97)$ with significant value $0.000<$ $0.05, \mathrm{H} 0$ rejected and $\mathrm{H} 1$ accepted. It means there is significant effect of service quality to customer satisfaction.

In addition, to determine the effect of relationship marketing, service quality, and customer satisfaction against customer loyalty, researcher doing partial correlation between each variable. 
Table 5. Results of the T-test (partial test) Model 2

\begin{tabular}{llccccc}
\hline \multirow{2}{*}{ Model } & \multicolumn{2}{c}{$\begin{array}{c}\text { standardized } \\
\text { coefficients }\end{array}$} & $\begin{array}{c}\text { Standardized } \\
\text { coefficients }\end{array}$ & \multirow{2}{*}{ t } & \multirow{2}{*}{ S.I.G. } \\
\cline { 2 - 5 } yes & Std. Error & Beta & & \\
\hline two & $\begin{array}{l}\text { (Constant) } \\
\text { Marketing }\end{array}$ & 2,278 & 1,485 & & 1,534 & .128 \\
$\begin{array}{l}\text { Relational } \\
\text { Quality }\end{array}$ & .189 & .133 & .168 & 1,419 & .159 \\
$\begin{array}{l}\text { Service } \\
\text { Satisfaction } \\
\text { Client }\end{array}$ & .042 & .94 & .499 & .449 & .654 \\
\hline
\end{tabular}

a. Dependent variable: Customer_Loyalty

Source: SPSS 23 output, data processed

Based on Table 5, it can be explained as follows:

Relationship marketing does not have significant direct effect on customer loyalty. It is observed that Relational Marketing has a t-test value of 1,419 <value of the ttable of $1,985(\alpha=5 \%, \mathrm{df}=96)$ or with a significance value of $0.159>0.05, \mathrm{H} 0$ is accepted and rejected $\mathrm{H} 1$. It can be conclude that relationship marketing does not have direct effect on customer loyalty.

Service quality does not have significantly direct effect to customer loyalty. It is because the Service Quality has a t-test value of 0.449 <value of the t-table of 1.985 $(\alpha=5 \%, \mathrm{df}=96)$ or with a significance value of $0.654>$ $0.05, \mathrm{H} 0$ accepted, and $\mathrm{H} 1$ rejected. It can be conclude that service quality does not have direct effect on customer loyalty.
Customer satisfaction found it has a significant direct effect on customer loyalty. Customer satisfaction has a t-value of $6,490>1,985(\alpha=5 \%, \mathrm{df}=96)$ or with significant value $0.000<0.05, \mathrm{H} 0$ is rejected and $\mathrm{H} 1$ accepted. Therefore, it can be concluded that partial customer satisfaction has a significant effect on customer loyalty.

Additionally, the researchers performed a path analysis test to see the relationship between relationship marketing and service quality with customer loyalty by making customer satisfaction an intervening variable. The analysis was carried out using simple mediation Model 4 Macro PROCESS with SPSS Ver 2.

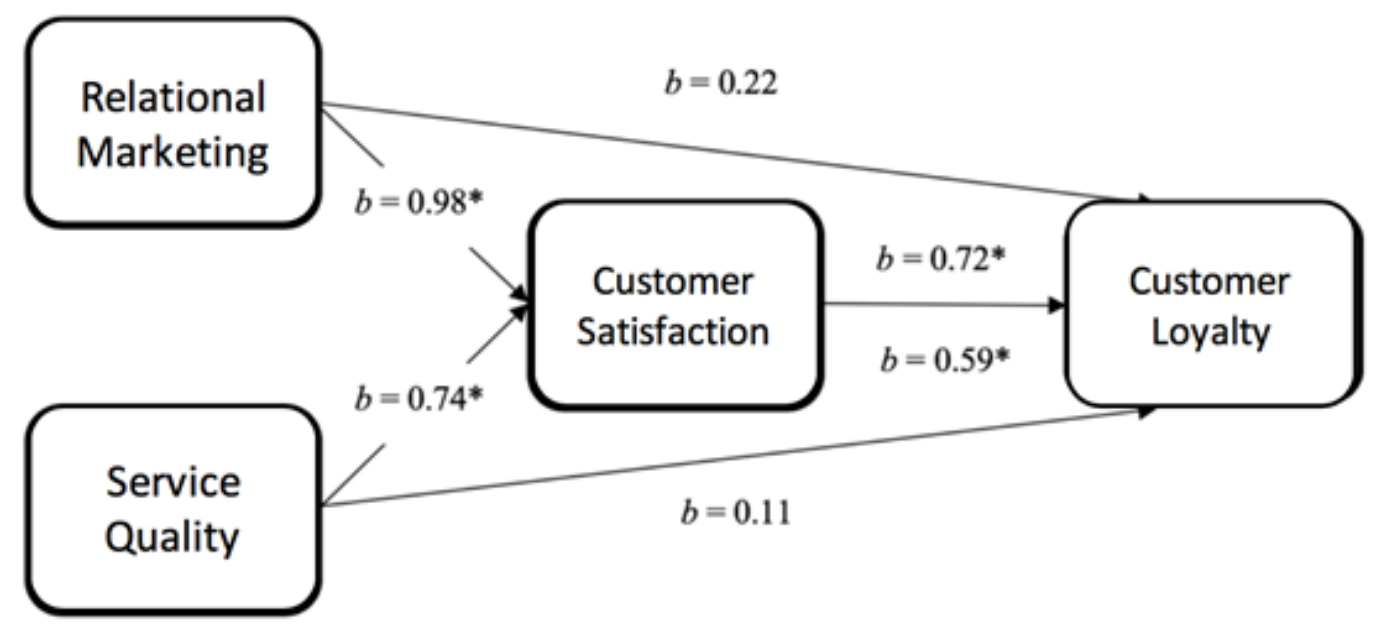

Fig 2:- Interpretation of path analysis

Based on the above image is known to relationship marketing has no significant impact on customer loyalty is directly ( $b=0.22 \mathrm{CI}, 95 \%[-0.00,0.44])$. This is in line with the partial tests done previously. However, with the basis in the test route analysis, it was obtained the result that relationship marketing has a significant indirect effect on the loyalty of the customer through the satisfaction of the customer $(b=0.98,95 \%$ CI [ $0.82,1,06])$. In other words, good relationship marketing will increase customer satisfaction, and customer satisfaction is what drives customer loyalty.

Service Quality also had no significant direct effect on customer loyalty $(b=0.11,95 \%$ CI [ 0. 04, 0:27 ]). However, the Service Quality has a very significant indirect influence on the loyalty of the customer through the mediation of the satisfaction of the customer ( $b=0.74,95 \%$ CI $[066,0,82]$ ). 
Based on this path analysis is also evident that customer satisfaction plays a role as explains the mediator entirely the influence of relationship marketing and service quality in customer loyalty. In other words, without customer satisfaction, relationship marketing and service quality will not generate customer loyalty.

\section{DISCUSSION}

\section{$>$ Relationship marketing affect customer satisfaction}

Based on the research results, relationship marketing is known to have a significant and positive effect on customer satisfaction. This is due to the t-statistical value of $5,199 \geq 1.96$, so it can be said to have a significant effect. Apriliani, Kumadji, and Kusumawati (2014) explained that customers were satisfied with sellers when they felt the social and functional benefits were occurring. The current concept of marketing focuses on building value-based marketing relationships and networks. A strong and mutually beneficial relationship between the company and the customer can help to repeat transactions and create customer loyalty (Hasan, 2013). The relationship marketing framework is continually building relationships with customers to build customer loyalty that can generate repeat transactions (Alma, 2013). Relationship marketing emphasises developing long-term ties to business services through personal interaction and connections with the business. Therefore, keeping customers is the primary key in a company to be more successful than its competitors. Research by Nauroozi, et al (2015) shows that relationship marketing has a positive and significant effect on customer satisfaction.

\section{$>$ Service quality affects customer satisfaction}

Based on the research results, service quality is known to have a significant and positive effect on customer satisfaction. This is due to the t-statistical value of $3,227 \geq$ 1.96 , so it can be said to have a significant effect. Quality drives clients to establish strong ties with the company. In the long term, this type of bonding enables companies to carefully understand customer expectations and needs so that companies can increase customer satisfaction by maximising a customer-friendly experience and minimising or eliminating a less customer bad experience (Lupiyoadi, 2013). Low quality will cause dissatisfaction with customers, not only customers who eat at the restaurant but also have an impact on others because disappointed customers will tell at least 15 other people. As a result, potential customers will make their choices over competitors (Kotler \& Keller, 2016). Efforts to improve the service quality system will be much more useful for business continuity. The results of this study are in line with the previous research carried out by Maimunah and Djawoto (2017) that establishes that the quality of the service has a positive and significant effect on customer satisfaction.
> The indirect effect of relationship marketing on customer loyalty with customer satisfaction as an intervening variable

The results showed that relationship marketing has a positive and significant effect on customer loyalty with customer satisfaction as an intervening variable. This is due to the t-statistical value of $3,915 \geq 1.96$, so it can be said to have a significant effect. There are several strategies that can be integrated to achieve and increase customer satisfaction, one of which is the relationship marketing strategy (Tjiptono, 2014). As is well known, relationship marketing is a strategy used by companies to foster longterm relationships with their clients (Hasan, 2013). If the company can carry out relationship marketing correctly, it will create customer satisfaction. Kotler and Armstrong (2014) revealed that most studies show that the higher the level of customer satisfaction, the higher the customer loyalty, which will result in better company performance. Previous research by Yulisetiarini (2016) shows that relationship marketing has a significant effect on customer loyalty with customer satisfaction as an intervening variable.

$>$ The indirect effect of Service Quality on customer loyalty with customer satisfaction as an intervening variable

The results showed that service quality has a positive and significant effect on customer loyalty with customer satisfaction as an intervention variable. This is due to the $t-$ statistical value of $2,246 \geq 1.96$, so it can be said to have a significant effect. Quality is closely related to customer satisfaction in determining customer loyalty. Quality drives clients to establish strong ties with the company. Ultimately, this type of bonding enables the company to understand customer expectations and needs carefully. Therefore, companies can increase customer satisfaction by providing pleasant services that will undoubtedly create great consumer loyalty towards the company (Tjiptono, 2014). Previous research by Carelse (2017) shows that service quality has a significant and positive effect on customer loyalty through customer satisfaction.

\section{$>$ Customer satisfaction affect customer loyalty}

The results showed that customer satisfaction had a significant and positive effect on customer loyalty. This is due to the t-statistical value of $5.585 \geq 1.96$, so it can be said to have a significant impact. Customer satisfaction is a feeling of pleasure or disappointment that appears after comparing customer perceptions or impressions with the results of a product and customer expectations. The success of the company if the employees can provide an excellent service, so that the customers feel satisfied and, in the eyes of the customers, the image of the company becomes excellent and positive (Sunyoto, 2015). Satisfied customers will have a direct impact on the emergence of a loyal attitude toward satisfying products and services. The study results are in line with previous research by Zephan (2018) that customer satisfaction has a significant and positive effect on customer loyalty. 


\section{CONCLUSION}

From this study we can conclude that:

The study results indicate that relationship marketing has a positive and significant effect on customer satisfaction. Good relationship marketing will create a customer satisfaction with the positive perception or impression.

> The results of the study indicate that service quality has a positive and significant effect on customer satisfaction, which means that it has a strong relationship between service quality and customer satisfaction. It is indicate that PTSI has a good service to make customer satisfied with the service or product.

> The results showed that relationship marketing has a positive and significant effect on customer loyalty with customer satisfaction as an intervening variable. Where in the factor of trust and retention buying has a great relationship If PTSI have a good trust, it will impact directly to the retention of buying.

$>$ The result showed that service quality has a positive and significant effect on customer loyalty with customers satisfaction as an intervening variable. It means customer loyalty cannot achieve without customer satisfaction.

> The results showed that customer satisfaction had a significant and positive effect on customer loyalty. This research shown that customer satisfaction generate the customer loyalty. If PTSI want to have loyal customers, PTSI should make them satisfy.

\section{ACKNOWLEDGEMENTS}

Based on some findings in this research, we can suggest:

$>$ It is recommended that companies increase customer confidence through the quality of each product offered. Additionally, it is recommended that companies display all company information, from proprietary products to transparency about the company's financial statements on a monthly or annual basis. This will increase customer confidence so that long-term relationships with customers to continue making repeat purchases can continue to improve.

It is recommended that employees of PT Precision Tools Service Indonesia can empathise with customer complaints and suggestions for the company's progress. Even periodically, companies can conduct customer satisfaction surveys and what recommendations can be given to the company.

$>$ It is recommended in future studies to use other variables that are tested to determine their influence on customer satisfaction and that have implications for customer loyalty.

\section{REFERENCES}

[1]. Akbar MM and Parvez. 2009. "Impact of service quality, trust and customer satisfaction loyalty". ABAC Magazine. Vol. 29, No. 1.

[2]. Alma, Buchari. 2013. Marketing management and marketing services. Bandung: Alphabeta.

[3]. Amalia, Dhika. 2015. "The effect of Service Quality on customer loyalty in CV. Ilham Motor Gandu Mlarak Ponorogo". To the Tijarah Journal. Vol. 1 No. 1

[4]. Anshari, Dhevina Dwi ., Wijaksana, Tri Indra. 2016. The effect of relationship marketing on customer loyalty through customer satisfaction (CV Study. Berkah Mandiri Surakarta, Central Java. EProceeding of Management. Vol. 3 No. 3.

[5]. Apriliani, Fitri., Kumadji, Srikandi ., And Kusumawati, Andriani. 2014. Effect

of relationship marketing on customer satisfaction and loyalty. (Case study at Banco Syariah Mandiri KC Bandar Jaya). Business Administration Magazine (JAB). Vol 17. No. 1.

[6]. Assauri, Sofjan. $2013 . \quad$ Marketing management. Jakarta: Rajawali Press.

[7]. Carelse, Bradford. 2017. "Investigate the impact of service quality and customer satisfaction on customer loyalty in life insurance in South Africa. Master of Commerce in Management. School of Business and Finance, University of the Western Cape

[8]. Cheng, C. and Lee, A., 2011. "The Influence of Relationship Marketing Strategy and Transaction Costs on Customer Satisfaction, Perceived Risk, and Customer Loyalty." African Journal of Business Management. Vol. 5 No. 3

[9]. Cockalo, Dragan and Zvonko Sajfert. 2011. "An explanatory study of relationship marketing and customer satisfaction in the Republic of Serbia". Southeast Europe Journal of Economics. Vol. 2

[10]. Daryanto 2011. Marketing direction: Sari Lecture. Bandung: A Nusa.

[11]. Dwi Liza Maimunah and Djawoto. 2017. Effect of service quality, price and corporate image on customer satisfaction. Journal of Management Sciences and Research Vol. 6. No. 12

[12]. Ghozali, Imam. 2014. Modelling of structural equations, alternative methods with partial least square (PLS). Number 4. Semarang: Editorial Board of the Diponegoro University.

[13]. Hasan, Ali. 2013. Marketing and selected cases. Yogyakarta CAPS (Academic Publication Service Center)

[14]. Hasugian, JTM 2015. "The effect of brand image and brand confidence on Telkomsel brand loyalty." Electronic journal of business administration. Vol. 3 No. 44 
[15]. Kotler, Philip and Kevin Lane Keller, 2016. Marketing management. 15th Edition. New York: Pearson Education, Inc.

[16]. Kotler, Philip and Armstrong Gary. 2014. Marketing principles. 12th Edition. Volume 1. Jakarta: Erlangga.

[17]. Kumadji, Srikandi and Andriani Kusumawati. 2014, "The Effect of Relationship Marketing on Customer Satisfaction and Loyalty (Syariah Mandiri KC Bandar Jaya Bank Customer Study)". Thesis . Brawijaya University, Malang

[18]. Kusumawati, Ika and Andarwati Djumilah H. 2017. "The effect of the quality of products and services on the cafeteria's customer loyalty ". Business Economics Magazine. Vol. 22 No. 2

[19]. Lovelock, Christopher, Jochen Wirtz and Jacky Mussry. 2012. Marketing services. 7th edition Erlangga: Jakarta

[20]. Lupiyoadi, Rambat. 2013. Marketing management services. Number 3. Jakarta: Fourth Salemba

[21]. Nauroozi and Sayed Eisa and Seiroos Korahi Moghadam. 2015. "The study of relationship marketing with customer satisfaction and loyalty". International Journal of Innovation and Research in Educational Sciences. Vol. 2 Issue. two

[22]. Hug her, Freddy. 2013. SWOT analysis techniques for dissecting business cases. Jakarta: PT. Gramedia's main library.

[23]. Sunyoto, Danang. 2015. Fundamentals of marketing management (concepts, strategies and cases). First impression. Yogyakarta: CAPS (Academic Publication Service Center).

[24]. Tiasanty, Lise. And Site, Arifin. 2019. Analysis of the effect of service quality, product quality and brand image on customer satisfaction and its implication on PT consumer loyalty. Sharp Electronics Indonesia (Case Study at Karawang Sharp Direct Service Station ). International Journal of Engineering Technologies and Management Research. Doi: 10.5281 / zenodo. 3271380

[25]. Tjiptono, Fandy. 2014. Marketing services: principles, implementation and research. Yogyakarta: Andi Offset.

[26]. Yulisetiarini, Diah. 2016. "The Effect of Relationship Marketing on Customer Satisfaction and Customer Loyalty in Franchised Retail Stores in East Java." Mediterranean Journal of Social Sciences, MCSER Publishing, Rome-Italy. Vol 7. No.1

[27]. Zephan, Njei. 2018. "Relationship between customer satisfaction and customer loyalty". Thesis. Centria University of Applied Sciences. 